\title{
THE IFO INDUSTRY GROWTH ACCOUNTING DATABASE
}

\author{
OLIVER ROEHN \\ THEO S. EICHER \\ THOMAS STROBEL
}

CESIFO WORKING PAPER No. 1915

Category 5: Fiscal Policy, Macroeconomics and Growth

FEBRUARY 2007

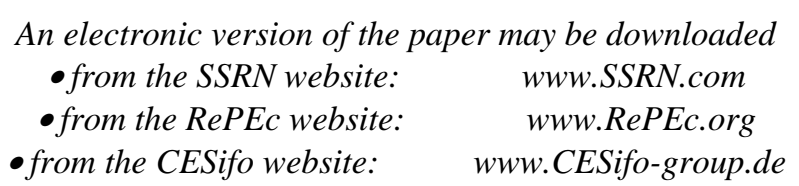




\title{
THE IFO INDUSTRY GROWTH ACCOUNTING DATABASE
}

\begin{abstract}
In this paper we present a new database that allows deep industry-level growth accounting from 1991-2003. The database allows for the first complete analysis of the German industry performance drivers based on the contributions of 12 asset types in 52 different industries. The industry sources of productivity and output growth are crucial to the understanding of the transformation of the German economy from manufacturing to information technology and service industries. The database enables researchers to develop an adequate picture of the sources of growth using standard growth accounting techniques. We formally document the new data series and its origins, with special focus on the capital stock and capital service data.

JEL Code: O4, O5.
\end{abstract}

Keywords: growth accounting, industry productivity analysis.

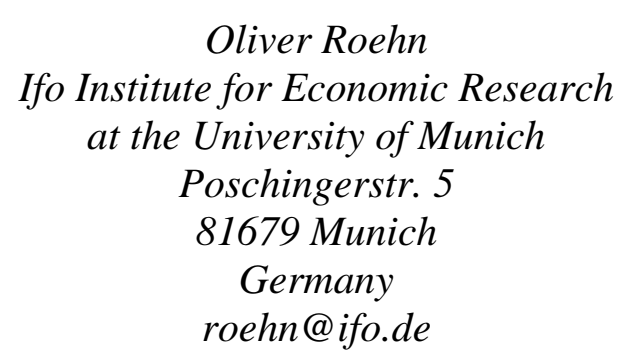

Theo S. Eicher

Department of Economics

University of Washington

301 Savery Hall, Box 353330

Seattle WA 98195-3330

USA

te@u.washington.edu

\author{
Thomas Strobel \\ Ifo Institute for Economic Research \\ at the University of Munich \\ Poschingerstr. 5 \\ 81679 Munich \\ Germany \\ strobel@ifo.de
}

January 2007

We thank Elke Kronjäger for sharing Ifo industry-level asset-specific investment data, Paul Schreyer for comments, Robert Inklaar for providing us with the unpublished German capital stock levels from the Groningen Industry Growth Accounting Database, and the German Science Foundation Grant \#524685 for financial support. 


\section{Introduction}

Growth accounting exercises are popular and often employed in productivity analyses to understand the underlying dynamics that determine the economic fortunes of countries. The need to illuminate the transition of industrialized nations from pure manufacturing to information and service based economies has emphasized the importance of growth accounting exercises as a means to identify structural shifts early and comprehensively. Key to such analyses is industry level investment data that distinguishes between all relevant assets types. In the US and other OECD countries, growth accounting exercises allow researchers to identify the effects of information and communication technology (ICT) investment on aggregate output and productivity. In Germany, however, no such data exists at the 52 industry level.

In this paper we present the Ifo Industry Growth Accounting Database that provides consistent investment and capital stock data for 12 investment assets in 52 industries from 1991 onward. ${ }^{1}$ The 12 assets are comprised of 3 ICT assets (Computer and Office Equipment; Communication Equipment; Software) and 8 additional equipment assets (Metal Products; Machinery; Electrical Generation and Distribution; Instruments, Optics and Watches; Furniture, Music and Sports Equipment; Other Machines and Equipment; Automobiles; Other Vehicles) as well as investments in Buildings and Structures. The 52 industries roughly correspond to the 2-digit industry-level NACE classification.

The Ifo Industry Growth Accounting Database is derived from the Ifo Investorenrechnung, which provides industry investment data based on investments in 100 different subassets. This detailed level of information allows us to allocate investments by asset type to each industry, using the Ifo investment flow matrix. We then use Jorgenson, Ho and Stiroh's (2005) growth accounting concepts to construct capital stock and capital service estimates for assets and industries.

The Ifo Industry Growth Accounting Database has three unique features. First, it provides information on an unprecedented number of German capital stocks and capital services at the industry level. Second, industry-level assets include three different types of ICT assets (Computer and Office Equipment; Communication Equipment; Software), which are of particular interest to understand the productivity performance of industries in the past decade. It is the first time that this level of ICT disaggregation is available at the German 52 industry level. Third, the detailed disaggregation of the different asset types and marginal productivities (measured as user costs) allows researchers to construct the most accurate

\footnotetext{
${ }^{1}$ The database is available at http://faculty.washington.edu/te/growthaccounting/
} 
measures of ICT and non-ICT capital services. To allow for complete German growth accounting, the database complements our original capital data with German Statistical Office (GSO) data on labor hours, labor quality, and value-added. Preliminary productivity analysis based on the database indicates a structural weakness in German ICT investment as well as a widespread collapse in TFP growth post-2000 (see Eicher and Roehn, 2007).

A similar productivity database exists at the Groningen Growth and Development Centre. Differences between the Ifo Industry Growth Accounting Database and the Groningen Industry Growth Accounting Database are fourfold. First, Groningen reports on 26 industries, while the Ifo Industry Growth Accounting Database contains 52 industries. Second, the Ifo Industry Growth Accounting Database includes Office Equipment in ICT assets, since Office Equipment and Computers cannot be separated at the German industrylevel. A third difference arises in the asset class entitled Buildings and Structures. The Ifo Industry Growth Accounting Database includes Residential and Non-Residential Buildings and Structures while Groningen includes only Non-Residential Buildings and Structures.

Finally, and perhaps most importantly, since German Software investments are not reported by the GSO, the Groningen database assumes that a fixed fraction of Intangible Assets is Software. Groningen then generates German industry-level Software investment by using a ratio of Software to IT-equipment investment that was obtained from an average of French, Dutch and US data. In contrast, the Ifo Industry Growth Accounting Database obtains data on Software investment shares in total Intangible Assets, and industry-level Software investment from an extensive (Ifo internal) survey based study by Herrmann and Mueller (1997) and from extensive industry level Ifo investment surveys in 1995, 1998, 1999, 2000.

The paper is structured as followed: Section 2 gives a brief overview of the underlying growth accounting methodology in the Ifo Industry Growth Accounting Database. Section 3 details the exact composition of the data in the Database. It describes the methodology used to obtain the input estimates and provides extensive information on all sources. Specifically, Section 3.1 focuses on the derivation of the capital input and Section 3.2 on the details of the labor inputs. Section 4 presents some results, while Section 5 concludes.

\section{Growth Accounting Framework}

The growth accounting framework allows us to decompose economic growth into the contributions from accumulated input factors and the residual: total factor productivity (TFP). The residual captures disembodied technological progress as well as all other 
productivity enhancing factors that are not explicitly measured. The framework is used to disentangle the sources of growth into the growth effects that can be attributed to factor accumulation and to productivity increases. Prominent applications of the growth accounting framework are the productivity slowdown beginning in the early seventies (e.g. Jorgenson and Yip, 2001), the examination of the growth miracle of the East Asian countries (e.g. World Bank, 1993) and analyses of the information and communication technology (ICT) revolution (e.g. Jorgenson and Stiroh, 2000, and Oliner and Sichel, 2000).

The breakdown of sectoral output growth into input factors, capital and labor, especially into ICT and non-ICT capital allows us to determine the underlying sources of aggregate output growth as well as of gains in productivity in times of rapid technological progress. In this section we introduce the growth accounting methodology and the data requirements to apply these techniques. The following chapters detail the sources and preliminary results of the Ifo Industry Growth Accounting Database.

The growth accounting framework employed in the Ifo Industry Growth Accounting Database is based on Jorgenson and Griliches (1967) and Jorgenson, Gollop and Fraumeni (1987). The database provides all data necessary for German industry level growth accounting exercises, that is, it includes data on output and input factors as well as data on all input shares. Detailed investment data is available on the industry-asset level, which allows us to dissect aggregate equipment assets into sectoral ICT and non-ICT assets. The database reports total factor productivity as well as labor productivity, and we focus on value-added as the relevant measure of industry output. The database does not report gross output since we lack appropriate deflators for intermediate inputs at the industry level. Jorgenson, Ho and Stiroh (2005) demonstrate that value-added TFP measures can be converted into gross output TFP measures using the share of nominal value added in nominal gross output.

Decomposing industry-level value-added growth into its input factors and TFP contributions requires detailed information on capital services and quality adjusted labor. Jorgenson, Ho and Stiroh (2005) commence with

$$
\Delta \ln V A_{i, t}=\bar{v}_{K, i, t} \Delta \ln K_{i, t}+\bar{v}_{L, i, t} \Delta \ln L_{i, t}+\Delta \ln T F P_{i, t}
$$

where $K_{i, t}$ and $L_{i, t}$ denote capital services and quality adjusted labor of industry $i$ and period $t$, respectively. When information on value-added, capital services and labor quality is at hand, total factor productivity growth, $\Delta \ln T F P_{i, t}$, can be derived as the residual. The two-period 
average nominal input shares of capital and labor are $\bar{v}_{K, i, t}$ and $\bar{v}_{L, i, t}$, respectively. They are given by

$$
\bar{v}_{h, i, t}=0.5\left(v_{h, i, t}+v_{h, i, t-1}\right) \text {, with } h=K, L \text {. }
$$

Where the input shares $v_{h, i, t}$ are defined as

$$
\begin{aligned}
& v_{K, i, t}=\frac{P_{K, i, t} K_{i, t}}{P_{V A, i, t} V A_{i, t}}, \\
& v_{L, i, t}=\frac{P_{L, i, t} L_{i, t}}{P_{V A, i, t} V A_{i, t}},
\end{aligned}
$$

and $P_{K, i, t}, P_{L, i, t}$ and $P_{V A, i, t}$ are the prices of capital, labor, and value-added, respectively. From the standard growth accounting assumption of constant returns to scale it follows that $v_{K, i, t}+v_{L, i, t}=1$. We can now rewrite equation (1) to derive average labor productivity (ALP) growth, defined as value-added per hour worked

$$
\Delta \ln A L P_{i, t}=\bar{v}_{K, i, t} \Delta \ln k_{i, t}+\bar{v}_{L, i, t} \Delta \ln q_{i, t}+\Delta \ln T F P_{i, t}
$$

where $\Delta \ln q_{i, t}$ represents labor quality growth and $\Delta \ln k_{i, t}$ reflects capital deepening. Equation (5) relates labor productivity growth to changes in capital deepening (when workers are matched with more and better capital), labor quality, and total factor productivity growth. TFP is often thought to capture technology, but it also reflects omitted variables, deviations from the assumption of constant returns to scale, market structure, and measurement errors.

\section{Data and Methods}

Equation (1) shows how the growth rate of value-added can be decomposed into the weighted growth rates of the input factors - capital and labor - and a residual (TFP). In this section we discuss how each of the ingredients of equation (1) can be estimated and provide the respective data sources. Value-added is directly taken from the GSO and we therefore focus our exposition on capital and labor input measures. The methodology is well established and a summary is provided in Jorgenson, Ho and Stiroh (2005) and recent applications can be found in Bureau of Labor Statistics (2000b). For an overview, Table 6 lists the sources of each variable employed in the Ifo Industry Growth Accounting Database.

\subsection{Capital Inputs: Capital Services and Capital Stocks}

\subsubsection{Estimating Capital Services}


Capital services, in contrast to capital stocks, are the flows of services by which each capital asset type contributes to the production process. It is the preferred capital measure in productivity analyses. Following Jorgenson, Ho and Stiroh (2005, p. 154) we assume capital services for an individual asset type to be proportional to the capital stock,

$$
K_{i, j, t}=Q_{K, i, j} \frac{1}{2}\left(S_{i, j, t-1}+S_{i, j, t}\right)
$$

Here the capital service flows of asset $j$ are the average of the current and past current value of capital stock $S_{i, j, t}$ (measured at the end of a period). The assumed proportionality between capital stocks and capital services implies that growth rates of stocks and services for each asset are identical. The distinction between capital stocks and services, however, becomes crucial when aggregating over different types of assets. To construct an aggregate index of capital services, we assume with Jorgenson, Ho and Stiroh (2005, pp. 158-162) that each asset is weighted by its marginal productivity. Under the assumption of competitive markets the marginal productivity can be measured as the price of capital services $P_{K, i, j, t}$, which as we show below is equal to the user cost of capital. An overall index of capital services can then be constructed as:

$$
\Delta \ln K_{i, t}=\sum_{j} \bar{\mu}_{i, j} \Delta \ln K_{i, j, t}
$$

where $\bar{\mu}_{i, j}=0.5\left(\mu_{i, j, t}+\mu_{i, j, t-1}\right)$, and $\mu_{i, j, t}=\frac{P_{K, i, j, t} K_{i, j, t}}{\sum_{j} P_{K, i, j, t} K_{i, j, t}}$. Equations (6) and (7) highlight the need for two important measures to derive capital service estimates on the industry level: capital stocks $S_{i, j, t}$ and the user costs of capital $P_{K, i, j, t}$ for each capital type. The rest of this section focuses on how capital stocks and user cost of capital are constructed in the Ifo Industry Growth Accounting Database.

\subsubsection{Estimating Capital Stocks}

\subsubsection{The Perpetual Inventory Method}

We use the perpetual inventory method (PIM) to derive our capital stock measures. According to the PIM, the stock of capital of asset $j$ in industry $i$ at the end of period $t, S_{i, j, t}$, evolves according to:

$$
S_{i, j, t}=S_{i, j, t-1}\left(1-\delta_{i, j}\right)+I_{i, j, t}=\sum_{\tau=0}^{\infty}\left(1-\delta_{i, j}\right)^{\tau} I_{i, j, t-\tau}
$$


where $I_{i, j, t}$ is investment in asset $j$ in industry $i$ at constant prices, and $\delta_{i, j}$ is the geometric depreciation rate of asset $j$ in industry $i$. Equation (8) simply states that the capital stock at the end of the period is the weighted sum of past investments where the weights reflect efficiency and retirement losses of older vintages of investment. The weights are the geometric depreciation rates. Depreciation rates are based on the age-efficiency profiles or age-price profiles of investment goods. The two time profiles are usually not identical, but they are related. While the age-efficiency profile is related to economic decay that affects the productive capacities of investments, the age-price profile refers to depreciation in terms of loss in value. The crucial point lies in how the patterns of decay and depreciation evolve over time with respect of each other. Hulten and Wykoff (1981a, 1981b, 1981c) and Fraumeni (1997) identified that the geometric pattern is the best description of economic depreciation. Another advantage of geometric depreciation rates over other forms of depreciation patterns is that the age-price profile and age-efficiency profile coincide. ${ }^{2}$

\subsubsection{Transforming Investment Series into Capital Stocks}

Equation (8) states that the generation of capital stocks based on the PIM requires long investment series in constant prices for each asset on the industry level. How far these investment series have to date back depends on the service life of an asset. For instance, Structures and Buildings require very long investment series due to their service lives of several decades.

The GSO provides investment series for all 12 asset types for Unified Germany (19912004) at the aggregate level. The GSO further provides industry-level investments for two asset types only, namely New Equipment and Other Assets and Structures and Buildings. To obtain industry level investments for all 12 asset types in constant 2000 euro prices, we utilize the Ifo Investorenrechnung. The Ifo Investorenrechnung breaks down the 12 asset types into 100 detailed subassets, for which investment data is collected (for a detailed list of the subdivision of the 12 asset types into the 100 subassets, see Table A.1 in the Appendix). The advantage of the deep partition into 100 subassets is that it simplifies the identification of purchasing industries. Additionally, the Ifo Investorenrechnung obtains information about the recipient industries directly from industry organizations or from specific Ifo Investment Survey questions. ${ }^{3}$ These pieces of information are then combined into an investment flow

\footnotetext{
${ }^{2}$ For the relationship between an age-efficiency and an age-price profile in case of geometric rates see Jorgenson, Ho and Stiroh (2005), p. 153, and OECD (2001a), p. 64.

${ }^{3}$ The Ifo Investment Survey follows the EU guidelines for harmonized business surveys and contains 70,000 German firms, 5000 of which are surveyed for each sample period. It is established as an excellent leading indicator of German investment; it is also incorporated in a number of other leading indicators, most prominently the European Commission's Economic Indicators of the Euro Zone.
} 
matrix (Abnehmer-Basismatrix) that links the 100 investment assets to the 52 industries. Based on the investment flow matrix the Ifo Investorenrechnung then produces industry investments that are compatible with aggregate GSO investment levels by asset types and by industries. For a detailed list of the assets and industries post-1991, see Table 1. A detailed description of the derivation and sources of investments provided by the Ifo Investorenrechnung can be found in the Appendix.

The Ifo Investorenrechnung does not provide specific information on Software investment. Software is included in the broader group of Intangible Assets. However, the allocation of Intangible Assets to the industries is derived from an Ifo study that estimated the industry investment shares in total Software investment based on survey questions about industry investment in purchased and own account Software in 1995 (see Hermann and Mueller, 1997). The Hermann and Mueller survey questions were again asked in 1998, 1999 and 2000 as part of the Ifo Investment Survey. The results of the surveys were used to further refine the industry investment shares and were incorporated into the user structure of the investment flow matrix. Herrmann and Mueller (1997) estimated that about 75\% of aggregate investment in Intangible Assets is Software investment. The Ifo Investorenrechnung holds that this percentage remained stable in subsequent surveys. To differentiate industry-level Software investment from investment in Intangible Assets, we therefore assume that $75 \%$ of industry investment in Intangible Assets is Software.

Establishing consistent investment series prior to 1991 is subject to three major challenges. First, the Ifo Investorenrechnung and the GSO, provide only investment series for West Germany prior to 1991. Second, the industry classification changed to NACE post1991. Pre-1991 the Ifo Investorenrechnung uses the older GSL WZ79 classification. Third, the asset classification has changed; pre-1991 the Ifo Investorenrechnung provides investments for 13 assets types that coincide only roughly with the 12 assets post-1991. For a detailed list of the pre- and post-1991 industry and asset classification schemes, see Tables 2 and 3.

To overcome these difficulties the basis for capital services in the Ifo Industry Growth Accounting Database is estimated as initial capital stocks for 1991. To calculate the initial capital stocks in 1991 we utilized two sources of information. First, the GSO provides net capital stock estimates on the 52-industry level for Unified Germany in 1991. However, these net capital stocks are only disaggregated into two broad asset types: Equipment and Other Assets and Structures and Buildings. To further disaggregate industry Equipment and Other Assets net capital stocks into our more detailed asset types we used information of the Ifo 
Asset Database. Based on the Ifo Investorenrechnung the Ifo Asset Database calculated net capital stocks for 13 assets types on the industry level for West Germany (1970-1991) according to the WZ79 industry classification scheme (for details see Gerstenberger et al., 1989).

To develop a comparable set of pre- and post-1991 industries, we use the GSO (1993) correspondence. The result is a set of 28 conforming industries; Table 4 displays the conversion key. This allowed us to convert industry assets by WZ79 industry classification to industry assets by the NACE classification. Next we convert pre-1991 assets into the new assets post-1991 classification (see Table 5). We use unpublished Communication Equipment investment series (1970-1991) provided by the Ifo Investorenrechnung to disaggregate Communication Equipment out of the broader group of Electrical Equipment investment. Information on Intangible Assets is not available prior to 1991, but the aggregate net capital stock for 1991 is provided by the GSO. The distribution of the aggregate capital stock into industries is based on the industry investment shares in 1991 as reported in the Ifo Investorenrechnung.

The procedure results in net capital stocks for 28 industry groups by new asset types. To distribute the capital stocks by asset to each of the sub-industries to establish a 52 industry database we use investment shares by asset in 1991. The asset capital stocks are then proportionally scaled so that the sum over all assets equals the GSO's Equipment and Other Assets net capital stock for each of the 52 industries. Finally, the capital stocks were deflated using the investment deflators detailed in the next section.

Since our method of establishing the initial capital stock levels differ from the construction of capital stock series in Groningen's Industry Growth Accounting Database ${ }^{4}$, we compare our initial capital estimates of the Ifo Industry Growth Accounting Database with Groningen's capital stocks in $1991 .^{5}$ To be able to make comparisons, we first aggregate our 52 industries to match Groningen’s 26 industries. Further, we aggregate our 12 capital asset types into two broad capital types: ICT capital and non-ICT capital. Figures 1 and 2 depict the high correlations of ICT and non-ICT initial capital stock levels between the Ifo Industry Growth Accounting Database and Groningen's capital stock levels in 1991. The correlation coefficient of the ICT and non-ICT capital stock levels are 0.97 and 0.95 , respectively. This

\footnotetext{
${ }^{4}$ Groningen Growth and Development Centre, Industry Growth Accounting Database, September 2006, online at http://www.ggdc.net/, updated from O'Mahony and van Ark (2003).

${ }^{5}$ We thank Robert Inklaar for making the unpublished capital stock levels of the Groningen's Industry Growth Accounting Database available to us.
} 
implies that the construction of the initial capital stock cannot be the source of any potentially substantial differences in the subsequent growth rates.

\subsubsection{Deflation of Investment}

Investment deflators transform recent vintages of investments into equivalent efficiency units of earlier vintages. The key feature of investment price indices that are based on constantquality units is that they account for price declines in goods that are characterized by fast technological progress. Computers, for instance, are such goods because their increased processing speed and storage capacity enhances their quality tremendously. Using the concept of comparable prices, the actual price of computers has continuously declined. Not accounting for such quality improvements overstates actual prices and results in lower real-term growth rates of computer investments. To overcome this measurement problem, hedonic regression approaches were applied for computers. This methodology was introduced by Cole et al. (1986) and developed further by the US Bureau of Economic Analysis and the US Bureau of Labor Statistics to capture price developments in the presence of rapidly increasing technological progress.

The Ifo Investorenrechnung provides price indices for each asset at the industry level. These price indices match the aggregate deflator of the GSO for each asset, for details see Gerstenberger et al. (1989):

$$
P_{j, t}^{G S O} I_{j, t}=\sum_{i} P_{i, j, t}^{\mathrm{Ifo}} I_{i, j, t}
$$

For non-ICT assets (numbered assets $j=1,2,4,6,7,8,9,10,12$ in Table 1) the Ifo Industry Growth Accounting Database employs the asset and industry specific deflators of the Ifo Investorenrechnung. To deflate ICT assets into constant-quality units, the Ifo Industry Growth Accounting Database employs the aggregate ICT-deflators for the assets Computer and Office Equipment, Communication Equipment and Software developed by Timmer, Ypma and van Ark (2003). These deflators follow the "harmonization"-method pioneered in Schreyer (2000, 2002). According to this method, price indices are based on US hedonic price indices adjusted for differences in general inflation levels between Germany and the United States. Thus, we rescale the Ifo industry-specific deflators to match the aggregate deflator of Timmer, Ypma and van Ark (2003) for all ICT-assets $(j=3,5,11)$ :

$$
P_{j, t}^{\text {Groningen }} I_{j, t}=\sum_{i} P_{i, j, t}^{I f f-a d j u s t e d} I_{i, j, t} \text {, where } P_{i, j, t}^{I f o-\text { adjusted }}=P_{i, j, t}^{I f o} P_{j, t}^{\text {Groningen }} / P_{j, t}^{G S O}
$$


This method preserves the industry price differences and at the same time assures that the deflators reflect an internationally comparable decline in ICT-asset prices over time. Sources for Groningen ICT deflators and non-ICT deflators are listed in Table 6.

\subsubsection{Depreciation Rates}

Geometric depreciation rates are the final ingredient necessary for the calculation of PIM capital stocks. Fraumeni (1997) derived the geometric depreciation rates, $\delta_{j}$, as a function of the declining-balance rate, $R_{j}$, and the asset's average service life, $T_{j}$ (industry dimension suppressed):

$$
\delta_{j}=\frac{R_{j}}{T_{j}}
$$

For details on the sources of used depreciation rates and input factors used to calculate depreciation rates see Table 6. For a complete list of the geometric depreciation rates applied see Table 7. We employed Ifo specific German data on average service lives on industryassets and combined them with the declining balance rate estimates for these assets from the US Bureau of Economic Analysis (BEA) as detailed in Fraumeni (1997). According to the $\mathrm{BEA}$, the declining balance rates are set to 1.65 for the equipment assets and 0.91 for Structures and Buildings. The underlying source of Ifo specific average service lives is an Ifo study conducted by Gerstenberger et al. (1989). The authors use primarily tax-lives to derive average values for economic service lives, which generally represent the minimum of the actual economic service lives. While economic service lives change over time, data on such changes does not exist. A time-dependent adjustment of service lives is not always feasible, therefore it is common in the literature to assume a reduction of the economic service lives of 25 percent, on average, over the period 1950 to 1986 (see Gerstenberger et al. 1989, pp. 5356). To assure that our industry-specific service lives are in line with GSO asset-specific average service lives, the industry-specific service lives are scaled so that the industry average for each asset matches the average service lives for each asset of the GSO as reported in UNECE (2004).

For ICT assets we use separate depreciation rates to generate data that is internationally comparable. For Communication Equipment and Software, we utilize the geometric depreciation rates calculated by Jorgenson and Stiroh (2000). For Computers and Office Equipment we use geometric depreciation rates from Van Ark et al. (2002). For Office Equipment the depreciation rates change over time. This reflects the fact that this asset category is comprised of asset types with very different depreciation rates. For example, 
computers have considerably shorter service lives than photocopiers. The varying depreciation rates, therefore, account for the fact that the composition of this asset category has changed over time, largely in the direction of a higher share of faster depreciating computers. Geometric depreciation rates for Automobiles are also taken from Jorgenson and Stiroh (2000).

\subsubsection{User Cost of Capital}

Capital displays different productivities in different asset classes, which is reflected in its price. In general the price of capital services is captured by the rental price of capital that reflects the marginal productivity of the invested capital. Consider a firm's investment decision, choosing between buying an asset or any other investment opportunity. In equilibrium a firm must be just indifferent between the two alternatives: investing the money $\left(P_{I, t}\right)$ to earn a nominal rate of return, or buying capital with the same amount of dollars, collecting a price of capital (rental price or user cost of capital) and then selling the depreciated asset at next period's price $\left(P_{I, t+1}\right)$. This implies the following investment arbitrage equation (Jorgenson, Ho and Stiroh, 2005, p. 154):

$$
\left(1+i_{t+1}\right) P_{I, i, j, t}=P_{K, i, j, t+1}+\left(1-\delta_{i, j}\right) P_{I, i, j, t+1}
$$

where nominal interest, $i_{t+1}$, earned on the acquisition price in period $t, P_{I, i, j, t,}$, must equal the depreciated acquisition price in period $t+1$ plus the price of capital, $P_{K, i, j, t+1}$. Rearranging (12) yields the familiar price of capital equation:

$$
P_{K, i, j, t+1}=\left(i_{t+1}-\pi_{i, j, t+1}\right) P_{I, i, j, t}+\delta_{i, j} P_{I, i, j, t+1}
$$

where $\pi_{i, j, t+1}$ is the percent change in the acquisition price of an investment good between period $t$ and $t+1$. The nominal interest rate, $i_{t+1}$, is the long-term interest rate for Germany derived from the OECD Economic Outlook Database (for sources see Table 6). Equation (13) simply states that the price of capital services in period $t+1$ must equal the real interest, $\left(i_{t+1}-\pi_{i, j, t+1}\right)$ paid on the acquisition price of capital in period $t$ plus the depreciation on the acquisition price of capital in period $t+1$.

\subsection{Labor Input}

Labor input data is provided for completeness in the Ifo Industry Growth Accounting Database. Much of this data is not new and can be obtained from the appropriate sources. At times we need to adjust the data to achieve the appropriate level of disaggregation. However, the novelty of the database lies in its investment and capital stock data. 


\subsubsection{Quality Adjusted Labor}

An hour of supplied labor can exhibit very different marginal productivities, depending for instance on the level of education, experience or gender of the employee. Similarly to capital services, this difference must be reflected when aggregating different kinds of labor into an overall measure of labor input. Jorgenson, Ho and Stiroh (2005) suggest as the appropriate labor input measure

$$
\Delta \ln L_{i, t}=\sum_{l} \bar{\omega}_{i, l} \Delta \ln H_{i, l, t}
$$

where $\bar{\omega}_{i, l}=0.5\left(\omega_{i, l, t}+\omega_{i, l, t-1}\right)$, and $\omega_{i, l, t}=\frac{P_{L, i, l, t} H_{i, l, t}}{\sum_{l} P_{L, i, l, t} H_{i, l, t}}$. The hours of type $l$ skills in industry $i$ at time $t$ are given by $H_{i, l, t}$, and the price (wage rate) of an hour of type $l$ in industry $i$ at time $t$ is given by $P_{L, i, l, t}$.

Equivalently, Jorgenson et al. (2005) show that labor input growth can also be written as:

$$
\Delta \ln L_{i, t}=\Delta \ln Q_{i, t}^{L}+\Delta \ln H_{i, t}
$$

where $\Delta \ln Q_{i, t}^{L}$ represents the growth rate of labor quality given by

$$
\Delta \ln Q_{i, t}^{L}=\sum_{l} \bar{\omega}_{i, l} \Delta \ln H_{i, l, t}-\Delta \ln H_{i, t} \text { and } H_{i, t}=\sum_{l} H_{i, l, t}
$$

Equation (16) expresses labor quality growth as the difference between weighted and unweighted growth rates of hours worked.

Our measure of industry labor quality growth $\Delta \ln Q_{i, t}^{L}$ is obtained from the Groningen Industry Level Growth Accounting Database as detailed in Inklaar, O’Mahony and Timmer (2005). However, Groningen's labor quality estimates are available for 26 broad industries only. To obtain labor quality growth for our 52 industries, we assumed that labor quality growth was the same among all sub-industries within a broad Groningen industry and equal to the broad industry growth rate. Inklaar et al. (2005) provide labor quality only until 2000. We use 1980-2000 data to extrapolate labor quality to 2003 using an AR process with optimal lag length (using the AIC, Final Prediction Error, Hannan-Quinn, and the Schwarz criterion (BIC)) for each industry to match the post-2000 aggregate labor quality growth provided by Schwerdt and Turunen (2006). 
Labor hours are obtained from the GSO. A problem emerges due to the fact that hours worked are available for 14 sectors only. Here we assume that hours worked per employee (including self-employed) in the 14 sectors resembles those of the respective disaggregated Ifo Industry Growth Accounting Database industries. Specifically, we compute the hours worked per employee for each of the 14 industries and multiply them by the numbers of employees in the respective disaggregated Ifo Industry Growth Accounting Database industries to obtain total hours worked for each of the 52 industries. For details on the sources of all labor input data, see Table 6 .

\subsubsection{The Labor Compensation Share}

As expressed in equation (1), the growth rate of labor inputs is weighted by the labor compensation share in total industry value-added. Labor compensation for employed workers is provided by the GSO (see Table 6 for detailed source). However, the GSO publishes no data on the compensation of self-employed workers. To adjust for self-employed workers in our measure of labor compensation, we apply the simplest assumption that compensation per self-employed is equal to the compensation of employed workers.

\section{Applications}

For a full overview of the applications that can be generated by the database we ask the reader to consult the voluminous literature on productivity studies summarized by Jorgenson et al. (2005). Initial work by Eicher and Roehn (2007) dissects German productivity growth on the basis of the database to highlight the specific industry contributions to German TFP growth. Figures 3a)-c), for example, plot the modified Harberger (1998) diagram for the individual industry TFP growth contributions for the three periods 1991-1995, 1995-2000 and 20002003. The vertical axis displays the cumulative industry contributions to aggregate TFP growth, while the horizontal axis plots the cumulative industry output share in total value added (Domar-weights, Domar, 1961). Industry nominal gross output data are directly taken from the GSO. The vertical distance between two points displays the TFP contribution of an individual industry.

Focusing first on the average TFP growth at the aggregate level across the three periods (displayed by the horizontal line), we find that aggregate TFP growth increased from $0.35 \%$ in $1991-1995$ to $0.47 \%$ in $1995-2000$. However, post-2000 total factor productivity growth collapsed to about $0 \%$ in Germany. What is striking, however, is the heterogeneity of TFP growth contributions at the disaggregated industry level outlined by Figures 3a)-c). The curves are surprisingly steep, indicating a bifurcated economy with either strong productivity gains or sharp productivity losses. Even more important is that the share of industries that 
contribute negatively is increasing dramatically over the three time periods. This is especially apparent if we compare the 1995-2000 and 2000-2003 periods in Figures 3 b), c). In 19952000, 17 industries experienced negative TFP growth rates, featuring large contractions in Other Business Services, Motor Vehicles and the Insurance industry. In 2000-2003, in contrast, 28 industries accounting for almost 50 percent of aggregate value added showed negative TFP growth.

Comparing the first two periods in Figures $3 \mathrm{a}$ ), b), it is striking that Wholesale Trade and Financial Intermediation increased their TFP contributions substantially between the two periods. The same is true for Office Machinery \& Computers and Communications. Of these industries only Wholesale Trade managed to increase its TFP growth contribution further post-2000 when TFP growth in Communication and Office Machinery \& Computer slowed, and Financial Intermediation TFP turned negative. Contributions from the Insurance, Machinery and the Government sector steadily declined over the three periods, pointing to severe problems within these industries. These industries started with positive TFP growth but showed negative TFP growth post-2000.

\section{Summary and Conclusion}

In this paper we have presented a new industry-asset level database that allows industry level growth accounting from 1991-2003 for 52 industries and 12 assets. We provide the methodological underpinnings necessary to produce the capital, labor and productivity estimates and presented some first results.

The database allows for the first time the analysis of German productivity drivers on the 52-industry level. We provide researchers with access to this database to study not only the determinants of economic growth and per capita income but also the drivers of the structural changes in the German economy since 1991 from manufacturing to an ICT-based, New Economy. 


\section{References}

Bureau of Economic Analysis, Methodology Papers, The Measurement of Depreciation in the NIPA's, July 1997, online at http://www.bea.gov/bea/articles/ NATIONAL/NIPAREL/1997/0797fr.pdf [access date: October $22^{\text {nd }}, 2006$ ].

Bureau of Labor Statistics (2000b), Multifactor Productivity Trends, 1998, USDL 00-267, September 21.

Cole, Rosanne, Y. C. Chen, Joan A. Barquin-Stolleman, Ellen R. Dullberger, Nurtan Helvacian, and James H. Hodge (1986), Quality-Adjusted Price Indexes for Computer Processors and Selected Peripheral Equipment, Survey of Current Business, Volume 66, No. 1 (January), 41-50.

Domar, Evsey (1961), On the Measurement of Technological Change, Economic Journal 71, No. 284 (December), pp. 709-729.

Eicher, Theo S. and Oliver Roehn (2007), Sources of German Productivity Demise - Tracing the Effects of Industry Level ICT Investment, German Economic Review, forthcoming.

Fraumeni, Barbara M. (1997), The Measurement of Depreciation in the U. S. National Income and Product Accounts, online at http://www.bea.gov/bea/articles/NATIONAL/ NIPAREL/1997/0797fr.pdf [access date: September, 13 ${ }^{\text {th }}, 2006$ ].

German Statistical Office (2002), Klassifikation der Wirtschaftszweige, Ausgabe 2003 (WZ 2003), Wiesbaden, online at http://www.destatis.de/download/d/klassif/wz03.pdf [access date: October, 20 ${ }^{\text {th }}$, 2006].

Gerstenberger, Wolfgang, Johannes Heinze, Marlies Hummel, and Kurt Vogler Ludwig (1989), Ifo Studien zur Strukturforschung 12, Ifo Institute for Economic Research, Munich, Germany.

Harberger, Arnold C. (1998), A Vision of the Growth Process, American Economic Review Volume 88, No. 1, pp. 1-32.

Hermann, Michael and Albert Mueller (1997), Ifo Studien zur Strukturforschung 26, Ifo Institute for Economic Research, Munich, Germany.

Hulten, Charles R., and Frank C. Wykoff (1981a), Economic Depreciation and the Taxation of Structures in United States Manufacturing Industries: An Empirical Analysis, In: The Measurement of Capital, ed. Dan Usher.

Hulten, Charles R., and Frank C. Wykoff (1981b), The Estimation of Economic Depreciation Using Vintage Asset Prices: An Application of the Box-Cox Power Transformation, Journal of Econometrics, Volume 15, No. 3 (April), pp. 367-396.

Hulten, Charles R., and Frank C. Wykoff (1981c), The Measurement of Economic Depreciation, In: Depreciation, Inflation, and the Taxation of Income from Capital, ed. Charles R. Hulten, Urban Institute Press, Washington D.C.

Inklaar, Robert, Mary O’Mahony, and Marcel P. Timmer (2005), ICT and Europe's Productivity Performance: Industry-level Growth Account Comparisons with the United States, Review of Income and Wealth, Volume 51, Issue 4, pp. 505-536.

Jorgenson, Dale W., and Zvi Griliches (1967), The Explanation of Productivity Change, The Review of Economic Studies, Volume 34, No. 3, pp. 249-283.

Jorgenson, Dale W., Frank M. Gollop and Barbara M. Fraumeni (1987), Productivity and U. S. Economic Growth, Harvard University Press, Cambridge. 
Jorgenson, Dale W., and Kevin J. Stiroh (2000), Raising the Speed Limit: US Economic Growth in the Information Age, Brookings Papers on Economic Activity, Volume 1, pp.125-211.

Jorgenson, Dale W., Mun S. Ho, and Kevin Stiroh (2005), Productivity - Information Technology and the American Growth Resurgence, Volume 3, MIT Press, Cambridge, Massachusetts, United States.

Jorgenson, Dale and Eric Yip (2001), Whatever Happened to Productivity Growth?, in: E.R. Dean, M.J. Harper and C. Hulton, eds.: New Developments in Productivity Analysis, Chicago: University of Chicago Press, pp. 205-246.

OECD (2001a), Measuring Productivity - Measurement of Aggregate and Industry-Level Productivity Growth, online at http://www.oecd.org/dataoecd/59/29/2352458.pdf [access date: October, $10^{\text {th }}$, 2006].

Oliner, Stephen D. and Daniel E. Sichel (2000), The Resurgence of Growth in the Late 1990s: Is Information Technology the Story?, Journal of Economic Perspectives, Volume 14, No. 4, Fall, pp. 3-22.

Schreyer, Paul (2000), The Contribution of Information and Communication Technology to Output Growth: A Study of the G7 Countries, STI Working Papers, No.2, OECD, Paris.

Schreyer, Paul (2002), Computer Price Indices and International Growth and Productivity Comparisons, Review of Economic and Wealth, Volume 48, No. 1, pp. 15-31.

Schwerdt, Guido and Jarkko Turunen (2006), Growth in Euro Area Labour Quality, ECB Working Papers, No. 575.

Timmer, Marcel, Gerard Ypma and Bart van Ark (2003), ICT in the European Union: Driving Productivity Divergence?, Groningen Growth and Development Center, Working Paper GD-67.

UNECE (2004), Survey of National Practices in Estimating Service Lives of Capital Assets (ECE Secretariat), Joint Meeting on National Accounts, $28^{\text {th }}-30^{\text {th }}$ April 2004, Geneva, online at http://www.unece.org/stats/documents/ces/ac.68/2004/18.add.2.e.pdf [access date: September, $15^{\text {th }}$, 2006].

Van Ark, Bart, Johanna Melka, Nanno Mulder, Marcel P. Timmer and Gerald Ypma and (2002), ICT Investment and Growth Accounts for the European Union, 1980-2000, Groningen Growth and Development Center, Research Memorandum GD-56.

World Bank (1993), The East Asian Miracle. Economic Growth and Public Policy, OxfordNew York, Oxford University Press. 
AGAM : Association of German Automobile Manufacturers

(Verband der Deutschen Automobilindustrie, VDA)

AGMEM : Association of German Machinery and Equipment

Manufacturing (Verband des Deutschen Maschinen- und

Anlagenbaus, VDMA)

FOA : Federal Office of Automobiles

(Kraftfahrtbundesamt, KBA)

GDDC : $\quad$ Groningen Growth and Development Centre

GIER : German Institute for Economic Research

(Deutsches Institut für Wirtschaftsforschung, DIW)

AGEEM : Association of German Electrical and Electronic

Manufactures (Zentralverband Elektrotechnik und

Elektroindustrie, e.V., ZVEI)

GSO : German Statistical Office

(Deutsches Statistisches Bundesamt)

IS Leasing : Ifo Investment Survey Leasing

(Ifo Investitionstest Leasing)

NA : National Accounts provided by GSO

(Volkswirtschaftliche Gesamtrechung, VGR des Deutschen

Statistischen Bundesamtes) 
Table 1

Ifo Industry Growth Accounting Database Industry and Asset Classification in accordance with National Accounts (NA)



Source: Ifo Industry Growth Accounting Database, Ifo Investorenrechnung 
Table 2

Asset Type Classifications Pre- and Post-1991

\begin{tabular}{|c|c|c|c|}
\hline Seq. Nr. & Pre-1991 Assets & Seq. Nr. & Post-1991 Assets \\
\hline 1 & Foundry Products & 1 & Metal Products \\
\hline 2 & Steel and Railed Vehicles & 2 & Machinery \\
\hline 3 & Machinery & 3 & Computers and Office Equipment \\
\hline 4 & Office Equipment & 4 & Electrical Generation and Distribution \\
\hline 5 & Automobiles & 5 & Communication Equipment \\
\hline 6 & Other Vehicles & 6 & Instruments, Optics and Watches \\
\hline 7 & Electrical Products & 7 & Furniture, Music and Sports \\
\hline 8 & Fine Mechanics & & Equipment \\
\hline 9 & Iron, Plate and Steel Products (IPS) & 8 & Other Machines and Equipment \\
\hline 10 & Musical Instruments, Toys and Sports & 9 & Automobiles \\
\hline & Equipment & 10 & Other Vehicles \\
\hline 11 & Wood Products & 11 & Intangible Assets \\
\hline 12 & Textiles & 12 & Structures (Non Residential and \\
\hline 13 & $\begin{array}{l}\text { Structures (Non Residential and } \\
\text { Residential) }\end{array}$ & & Residential) \\
\hline
\end{tabular}

Source: Ifo Investorenrechnung, Gerstenberger et al. (1989) 
Table 3

Pre- and Post-1991 Industry Classification

Seq. Nr. Pre-1991 Industries

1 Agriculture, Forestry, Fishing

2 Electricity

3 Gas

4 Water Supply

5 Mining

6 Chemicals

7 Petroleum

8 Plastic

9 Rubber

10 Quarrying

11 Fine Ceramics

12 Glass

13 Iron-Producing Industries

14 Non-Iron Metal Products

15 Foundry

16 Extrusion, Railed Vehicles

17 Steel-, Light Metal-Working, Railed Vehicles

18 Machinery

19 Office Machinery and Computers

20 Manufacturer Leasing Office Machinery and Computers

21 Road Vehicle Manufacturing

22 Shipbuilding

23 Aerospace Manufacturing

24 Electrical Apparatus n.e.c.

25 Manufacturer Leasing Electrical Apparatus n.e.c.

26 Fine Mechanics, Optics

27 Iron, Plate and Metal Manufacturing

28 Music Instruments., Toys, Sports Equipment

29 Wood Working

30 Wood Products

31 Paper, Pulp

32 Paper, Pulp Products

33 Publishing, Printing

34 Leather

35 Textiles

36 Apparel

37 Food

38 Construction

39 Wholesale Trade

40 Retail Trade

41 Railways

42 Water Transport

43 Other Transportation

44 German Federal Mail

45 Financial Intermediation

46 Insurance

47 Apartment Leasing

48 Hotels and Restaurants

49 Education, Science, Art, Publication

50 Health, Veterinary

51 Other Services

52 Leasing Companies

53 Commercial Residential Buildings

54 Real Estate Fund, Asset Management

55 Local Authorities, Social Securities

56 Private Organization without Pecuniary Reward

\section{Seq. Nr. Post-1991 Industries}

1 Agriculture, Forestry, Fishing

2 Energy Mining and Quarrying

3 Mining and Quarrying, ex. Energy

4 Food and Tobacco

5 Textiles

6 Apparel

7 Leather

8 Wood Products

9 Paper, Pulp

10 Publishing, Printing

11 Coke, Petroleum, Nuclear Fuels

12 Chemicals

13 Rubber, Plastic

14 Non-Metallic Mineral Products

15 Basic Metals

16 Fabricated Metal Products

17 Machinery

18 Office Machinery and Computers

19 Electrical Apparatus n.e.c.

20 Radio, TV and Comm. Equipment

21 Instruments, Optics and Watches

22 Motor Vehicles

23 Other Transport Equipment

24 Furniture and Manufacturing n.e.c.

25 Recycling

26 Electricity, Gas

27 Water Supply

28 Construction

29 Sale and Repair of Motor Vehicles

30 Wholesale Trade

31 Retail Trade

32 Hotels and Restaurants

33 Land Transport

34 Water Transport

35 Air Transport

36 Auxiliary Transport Activities

37 Communications

38 Financial Intermediation

39 Insurance

40 Auxiliaries Financial and Insurance Intermediation

41 Real Estate

42 Rental and Leasing Services

43 Computer and Related Activities

44 Research and Development

45 Other Business Services

46 Public Administration, Defense, Social Security

47 Education

48 Health and Social Work

49 Sewage and Refuse Disposal

50 Organizations, n.e.c

51 Recreational, Cultural, Sports Activities

52 Other Services

Source: Ifo Investorenrechnung, Gerstenberger et al. (1989) 
Table 4

Industry Conversion Key: Pre- to Post-1991 Industry Classification

\begin{tabular}{|c|c|c|c|}
\hline Seq. Nr. & Pre-1991 Industries & Seq. Nr. & Post-1991 Industries \\
\hline 1 & Agriculture, Forestry, Fishing & 1 & Agriculture, Forestry, Fishing \\
\hline 5 & Mining & 2 & Energy Mining and Quarrying \\
\hline 7 & Petroleum & 3 & Mining and Quarrying, excl. Energy \\
\hline 10 & Quarrying & 11 & Coke, Petroleum, Nuclear Fuels \\
\hline 11 & Fine Ceramics & 14 & Non-Metallic Mineral Products \\
\hline 12 & Glass & & \\
\hline 37 & Food & 4 & Food and Tobacco \\
\hline 35 & Textiles & 5 & Textiles \\
\hline 36 & Apparel & 6 & Apparel \\
\hline 34 & Leather & 7 & Leather \\
\hline 28 & Music Instruments, Toys, Sports Equipment & 8 & Wood Products \\
\hline 29 & Wood Working & 24 & Furniture and Manufacturing n.e.c. \\
\hline 30 & Wood Products & & \\
\hline 31 & Paper, Pulp & 9 & Paper, Pulp \\
\hline 32 & Paper, Pulp Products & & \\
\hline 33 & Publishing, Printing & 10 & Publishing, Printing \\
\hline 6 & Chemicals & 12 & Chemicals \\
\hline 9 & Plastic & 13 & Rubber, Plastic \\
\hline 8 & Rubber & & \\
\hline 13 & Iron-Producing Industries & 15 & Basic Metals \\
\hline 14 & Non-Iron Metal Products & & \\
\hline 15 & Foundry & & \\
\hline 16 & Extrusion & & \\
\hline 17 & Steel-, Light Metal-Working, Railed Vehicles & 16 & Fabricated Metal Products \\
\hline 27 & Iron, Plate and Metal Manufacturing & & \\
\hline 18 & Machinery & 17 & Machinery \\
\hline 19 & Office Machinery and Computers & 18 & Office Machinery and Computers \\
\hline 24 & Electrical Apparatus n.e.c. & 19 & Electrical Apparatus n.e.c. \\
\hline \multirow[t]{2}{*}{26} & Fine Mechanics, Optics & 20 & Radio, TV and Comm. Equipment \\
\hline & & 21 & Instruments, Optics and Watches \\
\hline 21 & Road Vehicle Manufacturing & 22 & Motor Vehicles \\
\hline 22 & Shipbuilding & 23 & Other Transport Equipment \\
\hline 23 & Aerospace Manufacturing & & \\
\hline 39 & Wholesale Trade & 25 & Recycling \\
\hline \multirow[t]{3}{*}{40} & Retail Trade & 29 & Sale and Repair of Motor Vehicles \\
\hline & & 30 & Wholesale Trade \\
\hline & & 31 & Retail Trade \\
\hline 2 & Electricity & 26 & Electricity, Gas \\
\hline 3 & Gas & & \\
\hline 4 & Water Supply & 27 & Water Supply \\
\hline 38 & Construction & 28 & Construction \\
\hline 48 & Hotels and Restaurants & 32 & Hotels and Restaurants \\
\hline 41 & Railways & 33 & Land Transport \\
\hline \multirow[t]{2}{*}{43} & Other Transportation & 35 & Air Transport \\
\hline & & 36 & Auxiliary Transport Activities \\
\hline 42 & Water Transport & 34 & Water Transport \\
\hline 44 & German Federal Mail & 37 & Communications \\
\hline 45 & Financial Intermediation & 38 & Financial Intermediation \\
\hline \multirow[t]{3}{*}{46} & Insurance & 39 & Insurance \\
\hline & & 40 & Auxiliaries Financial and Insurance \\
\hline & & & Intermediation \\
\hline 47 & Apartment Leasing & 41 & Real Estate \\
\hline 53 & Commercial Residential Buildings & & \\
\hline 20 & Manufacturer Leasing Office Machinery and & 42 & Rental and Leasing Services \\
\hline & Computers & & \\
\hline 25 & Manufacturer Leasing Electrical Apparatus n.e.c. & & \\
\hline 52 & Leasing Companies & & \\
\hline 51 & Other Services & 43 & Computer and Related Activities \\
\hline \multirow[t]{2}{*}{54} & Real Estate Fund, Asset Management & 45 & Other Business Services \\
\hline & & 52 & Other Services \\
\hline \multirow[t]{3}{*}{49} & Education, Science, Art, Publication & 44 & Research and Development \\
\hline & & 47 & Education \\
\hline & & 51 & Recreational, Cultural, Sports Activities \\
\hline 50 & Health, Veterinary & 46 & Public Administration, Defense, Social Security \\
\hline 55 & Local Authorities, Social Securities & 48 & Health and Social Work \\
\hline \multirow[t]{2}{*}{56} & Private Organization without Pecuniary Reward & 49 & Sewage and Refuse Disposal \\
\hline & & 50 & Organizations, n.e.c \\
\hline
\end{tabular}

Source: based on German Statistical Office (2002) 
Table 5

Asset Conversion Key: Pre- to Post-1991 Asset Type Classification

\begin{tabular}{|c|c|c|}
\hline Pre-1991 Assets & Post-1991 Assets & Notes \\
\hline $\begin{array}{l}\text { Foundry Products; } \\
\text { Steel and Railed Vehicles; } \\
\text { Iron, Plate and Steel Products (IPS) }\end{array}$ & Metal Products & $\begin{array}{l}\text { 1) Metal products sum of Foundry } \\
\text { Products, Steel and Railed Vehicles, } \\
\text { Iron, Plate and Steel Products (IPS) } \\
\text { 2) For transport services: Metal } \\
\text { Products only sum of Foundry and } \\
\text { IPS, capital stocks in Steel are railed } \\
\text { vehicles and thus allocated to Other } \\
\text { Vehicles. }\end{array}$ \\
\hline Machinery & Machinery & \\
\hline Office Equipment & Office Equipment & \\
\hline $\begin{array}{l}\text { Electrical Products; } \\
\text { Fine Mechanics }\end{array}$ & $\begin{array}{l}\text { Electrical Generation and } \\
\text { Distribution; } \\
\text { Communication Equipment; } \\
\text { Instruments, Optics and Watches }\end{array}$ & $\begin{array}{l}\text { 1) Communication Equipment capital } \\
\text { stock broken out of Electrical } \\
\text { Products based on 11-year-average } \\
\text { (1980-1991) investment share in } \\
\text { Electrical Products. } \\
\text { 2) Sum of Electrical Products } \\
\text { (excluding Communication) and Fine } \\
\text { Mechanics split up into Electrical } \\
\text { Generation and Distribution } \\
\text { and into Instruments, Optics and } \\
\text { Watches according to } 1991 \\
\text { investment share. }\end{array}$ \\
\hline Musical Instruments, Toys and Sports & & Furniture, Music and Sports \\
\hline Equipment; & Furniture, Music and Sports & Equipment sum of Musical \\
\hline $\begin{array}{l}\text { Wood Products; } \\
\text { Textiles }\end{array}$ & Equipment & $\begin{array}{l}\text { Instruments, Toys and Sports } \\
\text { Equipment. Wood Products. Textiles. }\end{array}$ \\
\hline Automobiles & Automobiles & \\
\hline Other Vehicles & Other Vehicles & \\
\hline $\begin{array}{l}\text { Structures (Non Residential and } \\
\text { Residential) } \\
\end{array}$ & $\begin{array}{l}\text { Structures (Non-Residential and } \\
\text { Residential) }\end{array}$ & \\
\hline--- & Other Machines and Equipment & $\begin{array}{l}\text { 1\% of every equipment asset } \\
\text { (excluding Automobiles and Other } \\
\text { Vehicles) is allocated towards the new } \\
\text { asset Other Machines and Equipment. }\end{array}$ \\
\hline --- & Software & $\begin{array}{l}\text { Aggregate Intangible Assets net } \\
\text { capital stock provided by GSO. } \\
\text { Industry allocation according to } \\
\text { investment shares in } 1991 \text {. Software is } \\
75 \% \text { of Intangible Assets. }\end{array}$ \\
\hline
\end{tabular}

Source: Ifo Investorenrechnung, Gerstenberger et al. (1989), Hermann and Müller (1997), and unpublished information from the GSO. 


\section{Table 6}

\section{Key Variables and Data Sources}

\begin{tabular}{ll}
\hline Variables & \\
Value-Added & $V A$, \\
& \\
& \\
Capital Input Share: & \\
- Price of Capital (User Cost of Capital) & $P_{K}$ \\
- Nominal Interest Rate & $i$ \\
& \\
& \\
- Sectoral Price Inflation & $\pi$ \\
- Acquisition Price of Capital & $P_{I}$ \\
- Depreciation Rate & $\delta$ \\
- Capital Services & $K$ \\
Capital Input (Capital Services): & $K$ \\
\hline - Proportionality Factor & $Q_{K}$ \\
& $S$ \\
- Capital Stocks: & $S^{1991}$ \\
- Initial Capital Stock & $\delta$ \\
- Geometric Depreciation & \\
Rates &
\end{tabular}

- Average Service Lives

- Investments

- Investment Deflators

Labor Input Share:

- Price of Labor
Asset (Seq. Nr.)

A, $P_{V A} V A$

\section{Computers and}

Office Equipment (2)

Communication Equip. (5)

Automobiles (9);

Software (11)

All asset types (1-12)

All asset types, excluding Structures and Buildings (1-11)

Metal Products (1); Machinery (2); Electrical Generation and Distribution (4); Instruments, Optics and Watches (6); Furniture,

Music and Sports

Equipment (7); Other

Machines and Equipment

(8); Other Vehicles (10);

Structures and Buildings

(12)

$I^{\text {Groningen }}$

ICT Assets $(3,5,11)$

$P^{\text {Ifo }}$

Non-ICT Assets (1, 2, 4, 6 , $7,8,9,10,12$ )

$v_{L}$

$P_{L}$

\section{Sources}

German Statistical Office (GSO), www.destatis.de,

Genesis Database:

- Series 81000BJ321, Federal National Accounts (NA),

Intermediate inputs, gross output, value added for Unified

Germany, WZ 2003: Industry classification of the NA, in current and 2000 prices (update November 2006)

Derived from equation (3)

Derived from equation (13)

10-year benchmark government bond yields, Germany, www.sourceoecd.org, OECD Databases/ Economic

Outlook: Statistics and Projections, EO79 Annex Tables: Interest rates and exchange rates

Investment deflators, see Capital Input (Capital Services)

Investment deflators, see Capital Input (Capital Services)

See Capital Input (Capital Services)

See Capital Input (Capital Services)

Derived from equation (6)

Assumes proportionality between capital services and capital stocks, used in equation (6)

Derived from equation (8)

Ifo Asset Database, Ifo Investorenrechnung, GSO

B. Van Ark, J. Melka, N. Mulder, M.P. Timmer and G.

Ypma (2002), p.23

Inklaar, Robert, Mary O’Mahony and Marcel P. Timmer (2003), Table A.4

Jorgenson, Dale W. and Kevin Stiroh (2000), Table B1

Estimates of average service lives of investments, on industry-asset level, Ifo Investorenrechnung

Estimates of means service lives of investments, United

Nations Economic Commissions for Europe (UNECE),

www.unece.org, Statistics/ Documents Library/ Economic Statistics, Joint Meeting on National Accounts (Geneva, 28-30 April 2004), 18/ ADD.2 Annex 2: Assets categories (ECE secretariat), p. 83

Bureau of Economic Analysis (BEA), www.bea.gov, Methodology Papers/ Fixed Assets and Consumer Durable Goods, The Measurement of Depreciation in the NIPA's, July 1997, Table 3

Ifo Investorenrechnung

GGDC, www.ggdc.net, Data/ Total Economy Growth Accounting Database/ Germany, Gross fixed capital formation (in constant and current prices)

Ifo Investorenrechnung

Derived from equation (4)

GSO, www.destatis.de, Genesis Database:

- Series 81000BJ323, Wages of employed workers (in

current prices; update November 2006)

- Series 81000BJ323, Numbers of employed workers (update November 2006)

- Series 81000BJ323, Numbers of employees, i.e. employed workers including self-employed (update

November 2006)

See Labor Input (Labor Services)

Derived from equation (15)

GDDC, www.ggdc.net, Data/ Industry Growth Accounting Database/ Germany, Quality of labor

GSO, www.destatis.de, Genesis Database:

- Series 81000BJ323, Hours worked for employees, i.e. employed workers including self-employed (update November 2006) 
Table 7

Geometric Depreciation Rates by Assets

\begin{tabular}{|c|c|c|c|}
\hline $\begin{array}{l}\text { Seq. } \\
\text { Nr. }\end{array}$ & Assets & $\begin{array}{l}\text { Geometric Depreciation } \\
\text { Rate }\end{array}$ & $\begin{array}{l}\text { Time } \\
\text { Series }\end{array}$ \\
\hline 1 & Metal Products & 0.092 & 1991-2003 \\
\hline 2 & Machinery (industry average) & 0.130 & 1991-2003 \\
\hline 3 & Computers and Office Equipment & $\begin{array}{l}0.243 \\
0.254 \\
0.295\end{array}$ & $\begin{array}{l}1991-1994 \\
1995-1999 \\
2000-2003\end{array}$ \\
\hline 4 & $\begin{array}{l}\text { Electrical Generation and Distribution (industry } \\
\text { average) }\end{array}$ & 0.097 & 1991-2003 \\
\hline 5 & Communication Equipment & 0.115 & 1991-2003 \\
\hline 6 & $\begin{array}{l}\text { Instruments, Optics and Watches (industry } \\
\text { average) }\end{array}$ & 0.114 & 1991-2003 \\
\hline 7 & $\begin{array}{l}\text { Furniture, Music and Sports Equipment (industry } \\
\text { average) }\end{array}$ & 0.099 & 1991-2003 \\
\hline 8 & $\begin{array}{l}\text { Other Machines and Equipment (industry } \\
\text { average) }\end{array}$ & 0.130 & $1991-2203$ \\
\hline 9 & Automobiles & 0.272 & 1991-2003 \\
\hline 10 & Other Vehicles (industry average) & 0.085 & 1991-2003 \\
\hline 11 & Software & 0.315 & 1991-2003 \\
\hline 12 & Structures and Buildings (industry average) & 0.012 & 1991-2003 \\
\hline
\end{tabular}

Source: B. Van Ark, J. Melka, N. Mulder, M.P. Timmer and G. Ypma (2002); Inklaar, Robert, Mary O’Mahony and Marcel P. Timmer (2003); Jorgenson, Dale W. and Kevin Stiroh (2000); Ifo Investorenrechnung; United Nations Economic Commissions for Europe (UNECE); Bureau of Economic Analysis (BEA). For further details, see Table 6. 
Figure 1

ICT Capital Stock Levels Comparison: Ifo and Groningen 1991



Figure 2

Non-ICT Capital Stock Levels Comparisons: Ifo and Groningen 1991




Figure 3

Industry TFP Contributions to German Total Factor Productivity Growth

a) 1991-1995



b) 1995-2000

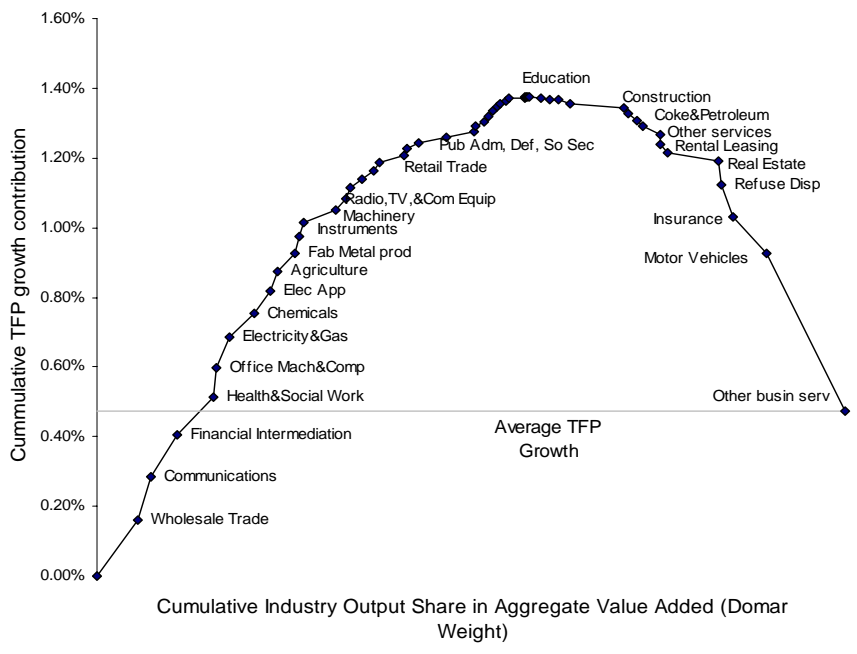

c) $2000-2003$



Source: Eicher and Roehn (2007) 


\section{Appendix}

\section{Original Investment Data}

The annual industry level investment data necessary to calculate capital stocks is provided by the Ifo Investorenrechnung from 1991 to 2003 and is documented in Gerstenberger et al. (1989). The Ifo Investorenrechnung collects 100 detailed subassets. Table A.1 lists the detailed subassets and their mapping to the 11 asset classes (excluding Structures and Buildings) used in the Ifo Industry Growth Accounting Database. Through individual agreements with each individual industry, the Ifo Investorenrechnung obtains annual investment data on all subassets. Specifically, the Ifo Investorenrechnung collects industry data on production, export and import, which then allows for the computation of domestically available production by subtracting the exports from the domestic production and adding the imports. In case of lacking industry data to calculate domestically available production in subassets, gross fixed investments provided by the GSO are used. The latter applies to the assets Metal Products; Computer and Office Equipment; Furniture, Music and Sports Equipment; Other Machines and Equipment; and Intangible Assets. For Other Vehicles gross fixed investments are provided by the German Institute for Economic Research (GIER). The sources of investments by subassets are listed in detail in Table A.2. To assure consistency to the GSO, the Ifo Investorenrechnung scales the 11 broader asset types to the respective GSO asset investments provided by the National Accounts (NA data provides gross fixed investments by all asset types as listed in Table A.3).

\section{Distribution of (Sub-)Asset Investments to Industries}

To distribute the GSO-adjusted investments by subassets to the industries, an Ifo investment flow matrix is used. This flow matrix contains a pre-determined user structure which relates the 100 subassets $^{6}$ to the 52 industries and therefore determines how much a certain industry uses of a particular subasset. More precisely, the user structure defines cells with 0 percentages, i.e. industries which do not use any of the subassets, and those with non-zero percentages. Sources for the determination of the percentages are Ifo Investment Survey questions, implicit industry specific information of a subasset category (e.g. the only user of food and packaging machines is the food industry), and explicit information of industry related associations (e.g. AGEEM, AGMEM). If none of the above sources is available, auxiliary indicators such as the size of an industry are used. This step results in a $52 \times 100$ investment matrix.

To eventually obtain a sectoral-subasset-investment matrix that is consistent with the GSO, GSO total investments by industries and GSO aggregate investment data by asset type serve as controls in each dimension of the matrix (sources listed in Table A.3). To assure that the column sums and row sums match the GSO controls, an iterative algorithm, the RASprocedure, is applied. The goal of this procedure is to leave the original user structures as unchanged as possible and at the same time to erase any discrepancies to the GSO controls. Finally, after aggregation across subassets and including sectoral investments for the $12^{\text {th }}$ asset Structures and Buildings as provided by the GSO, a 52x12 sectoral-asset-investment matrix is obtained. This sectoral-asset-investment matrix is available in current prices and in 2000 prices. $^{7}$

\footnotetext{
${ }^{6}$ The user structure of the investment flow matrix was updated in the mid-1990s and then extended to incorporate 100 subasset types in 2002 due to the change of subasset classes in Automobiles. Prior to 2002, 88 subassets were implemented.

${ }^{7}$ The Ifo Investorenrechnung additionally collects leasing data from the Ifo Investment Survey Leasing, which enables conversions from the ownership to the economic usage concept.
} 
Table A.1

Ifo Investorenrechnung Asset and Subasset Categories

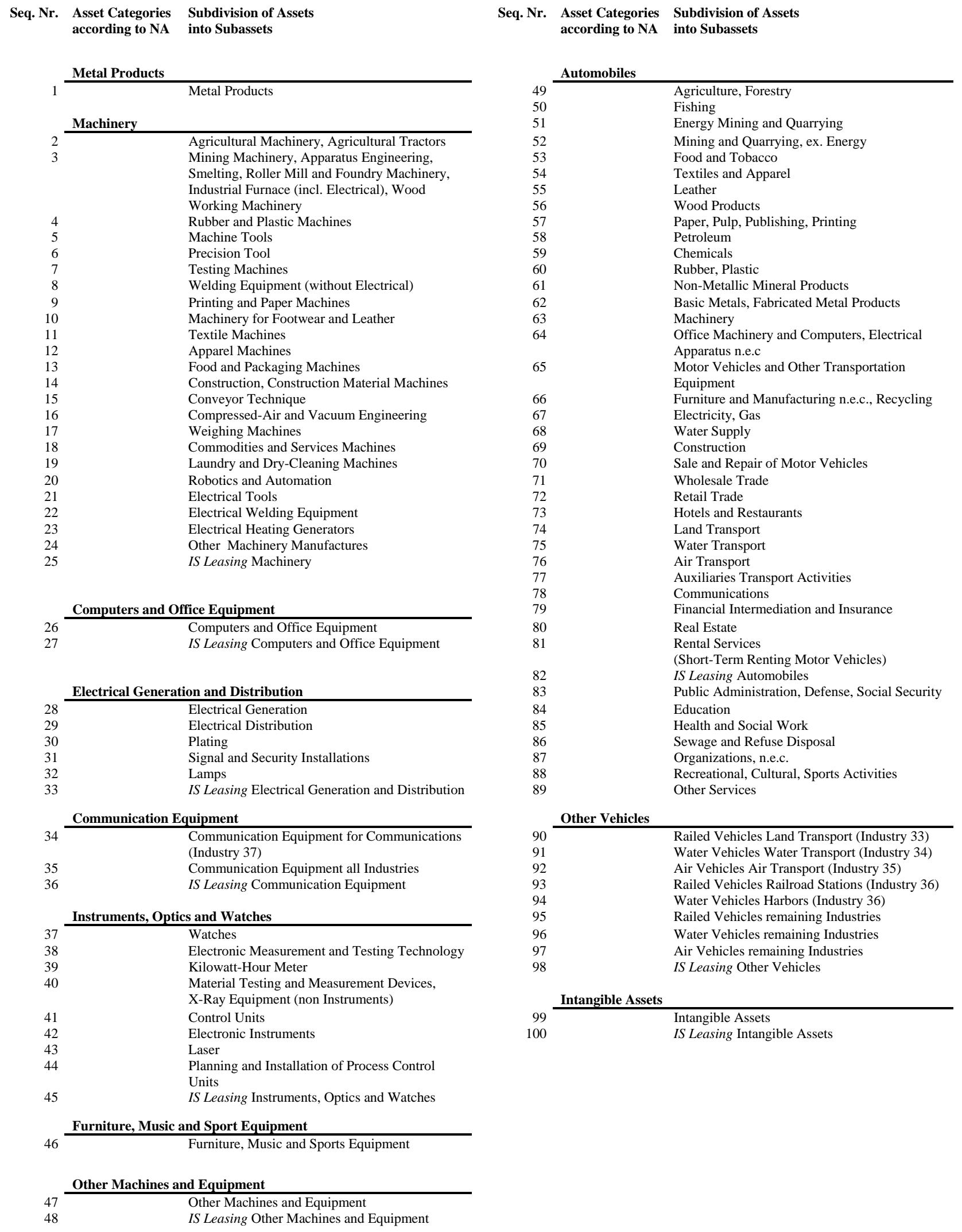

Source: Ifo Investorenrechnung 
Table A.2

Ifo Investorenrechnung Investment Data Sources by (Sub-)Assets

\author{
Seq. Nr. Asset Categories \\ 1 Metal Products (1) \\ 2 Machinery (2-24) \\ 3 Computers and Office Equipment (26) \\ 4 Electrical Generation and Distribution (28-32) \\ 5 Communication Equipment (34-35) \\ 6 Instruments, Optics and Watches (37-44) \\ 7 Furniture, Music and Sports Equipment (46) \\ 8 Other Machines and Equipment (47) \\ 9 Automobiles (49-89, excl. 82)
}

\section{Sources}

National Accounts (NA), GSO: Calculation of gross domestic product, detailed annual accounts, Journal 18, Series 1.4, 3.3.7 Gross fixed investments by assets

Association of German Machinery and Equipment Manufacturing (AGMEM): Production, export and import figures of machinery products according to AGMEM categories, Yearbooks

National Accounts (NA), GSO: Calculation of gross domestic product, detailed annual accounts, Journal 18, Series 1.4, 3.3.7 Gross fixed investments by assets

Association of German Electrical and Electronic Manufactures (AGEEM): Production, export and import figures of electrical investment products, ELVIRA Database

Association of German Electrical and Electronic Manufactures (AGEEM): Production, export and import figures of electrical investment products, ELVIRA Database

Association of German Electrical and Electronic Manufactures (AGEEM): Production, export and import figures of electrical investment products, ELVIRA Database

National Accounts (NA), GSO: Calculation of gross domestic product, detailed annual accounts, Journal 18, Series 1.4, 3.3.7 Gross fixed investments by assets

National Accounts (NA), GSO: Calculation of gross domestic product, detailed annual accounts, Journal 18, Series 1.4, 3.3.7 Gross fixed investments by assets

Federal Office of Automobiles (FOA): Numbers of new car registrations and trailers by groups of users and by car/ assembly types (for trucks and trailers), Monthly Reports, KBA-file by detailed groups of users (liable to pay costs)

Association of German Automobile Manufactures (AGAM): Production figures of the German automobile industry, import and export figures of automobiles by foreign trade product numbers, official foreign trade statistics (specialized trade), Annual Reports

German Institute for Economic Research (GIER): Gross fixed investments in vehicles, railed vehicles, water transport, public transport, truck transport, airlines and airports, Traffic in Numbers (liable to pay costs)

National Accounts (NA), GSO: Calculation of gross domestic product, detailed annual accounts, Journal 18, Series 1.4, 3.3.7 Gross fixed investments by assets

Note: Data for the subassets IS Leasing is provided by the Ifo Investment Survey Leasing. 
Table A.3

Investment Data Sources by Assets and Industries

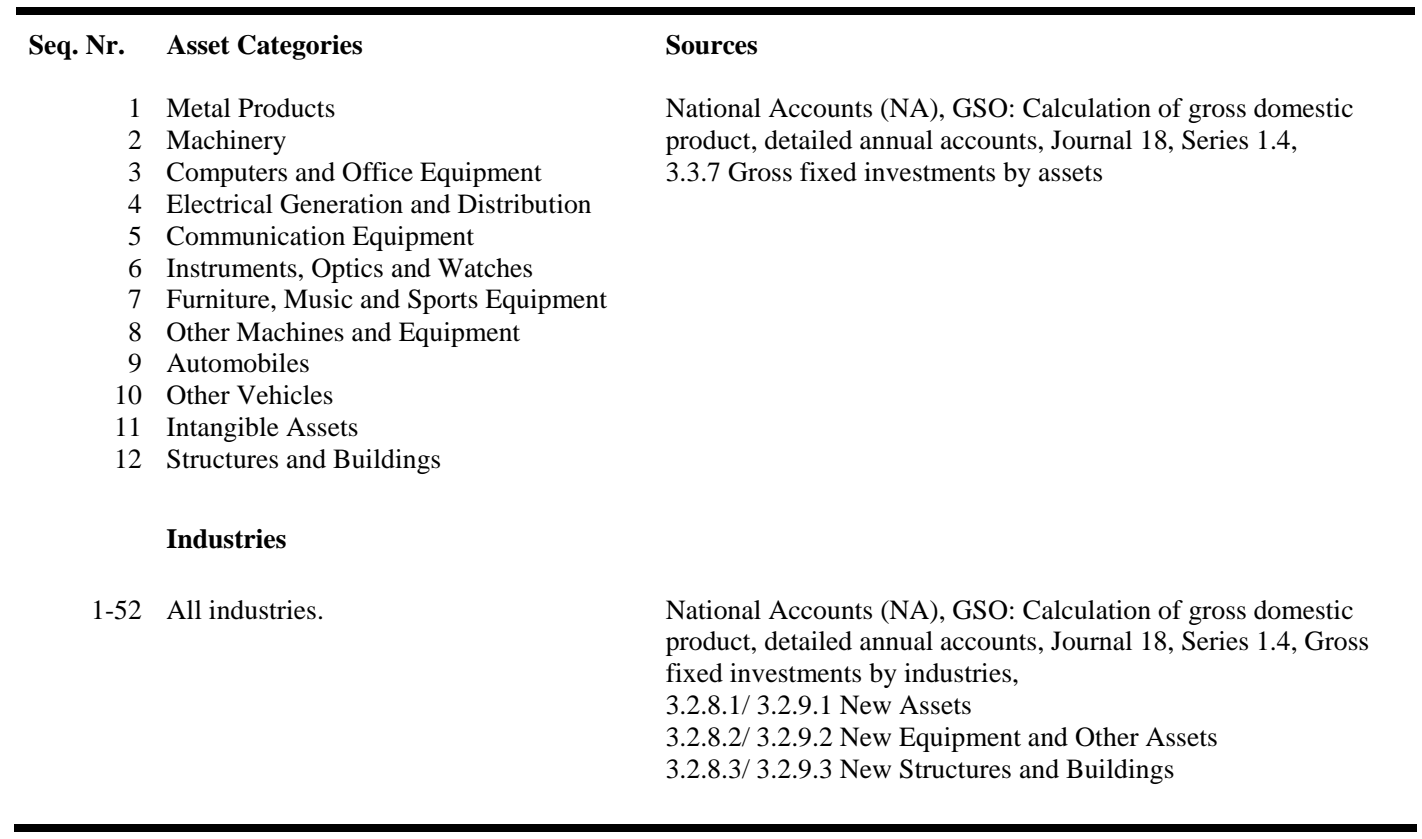




\section{CESifo Working Paper Series}

(for full list see www.cesifo-group.de)

1856 Biswa N. Bhattacharyay, Understanding the Latest Wave and Future Shape of Regional Trade and Cooperation Agreements in Asia, November 2006

1857 Matz Dahlberg, Eva Mörk, Jørn Rattsø and Hanna Ågren, Using a Discontinuous Grant to Identify the Effect of Grants on Local Taxes and Spending, November 2006

1858 Ernesto Crivelli and Klaas Staal, Size and Soft Budget Constraints, November 2006

1859 Jens Brøchner, Jesper Jensen, Patrik Svensson and Peter Birch Sørensen, The Dilemmas of Tax Coordination in the Enlarged European Union, November 2006

1860 Marcel Gérard, Reforming the Taxation of Multijurisdictional Enterprises in Europe, "Coopetition" in a Bottom-up Federation, November 2006

1861 Frank Blasch and Alfons J. Weichenrieder, When Taxation Changes the Course of the Year - Fiscal Year Adjustments and the German Tax Reform 2000/2001, November 2006

1862 Hans Jarle Kind, Tore Nilssen and Lars Sørgard, Competition for Viewers and Advertisers in a TV Oligopoly, November 2006

1863 Bart Cockx, Stéphane Robin and Christian Goebel, Income Support Policies for PartTime Workers: A Stepping-Stone to Regular Jobs? An Application to Young LongTerm Unemployed Women in Belgium, December 2006

1864 Sascha O. Becker and Marc-Andreas Muendler, The Effect of FDI on Job Separation, December 2006

1865 Christos Kotsogiannis and Robert Schwager, Fiscal Equalization and Yardstick Competition, December 2006

1866 Mikael Carlsson, Stefan Eriksson and Nils Gottfries, Testing Theories of Job Creation: Does Supply Create Its Own Demand?, December 2006

1867 Jacques H. Drèze, Charles Figuières and Jean Hindriks, Voluntary Matching Grants Can Forestall Social Dumping, December 2006

1868 Thomas Eichner and Marco Runkel, Corporate Income Taxation of Multinationals and Unemployment, December 2006

1869 Balázs Égert, Central Bank Interventions, Communication and Interest Rate Policy in Emerging European Economies, December 2006

1870 John Geweke, Joel Horowitz and M. Hashem Pesaran, Econometrics: A Bird's Eye View, December 2006 
1871 Hans Jarle Kind, Marko Koethenbuerger and Guttorm Schjelderup, Taxation in TwoSided Markets, December 2006

1872 Hans Gersbach and Bernhard Pachl, Cake Division by Majority Decision, December 2006

1873 Gunther Schnabl, The Evolution of the East Asian Currency Baskets - Still Undisclosed and Changing, December 2006

1874 Horst Raff and Michael J. Ryan, Firm-Specific Characteristics and the Timing of Foreign Direct Investment Projects, December 2006

1875 Jukka Pirttilä and Håkan Selin, How Successful is the Dual Income Tax? Evidence from the Finnish Tax Reform of 1993, December 2006

1876 Agnieszka Stążka, Sources of Real Exchange Rate Fluctuations in Central and Eastern Europe - Temporary or Permanent?, December 2006

1877 Xavier Calsamiglia, Teresa Garcia-Milà and Therese J. McGuire, Why do Differences in the Degree of Fiscal Decentralization Endure?, December 2006

1878 Natacha Gilson, How to be Well Shod to Absorb Shocks? Shock Synchronization and Joining the Euro Zone, December 2006

1879 Scott Alan Carson, Modern Health Standards for Peoples of the Past: Biological Conditions by Race in the American South, 1873 - 1919, December 2006

1880 Peter Huber, Michael Pfaffermayr and Yvonne Wolfmayr, Are there Border Effects in the EU Wage Function?, December 2006

1881 Harry Flam and Håkan Nordström, Euro Effects on the Intensive and Extensive Margins of Trade, December 2006

1882 Panu Poutvaara and Mikael Priks, Hooliganism in the Shadow of the 9/11 Terrorist Attack and the Tsunami: Do Police Reduce Group Violence?, December 2006

1883 Ruud A. de Mooij and Gaëtan Nicodème, Corporate Tax Policy, Entrepreneurship and Incorporation in the EU, December 2006

1884 Johannes Becker and Clemens Fuest, Corporate Tax Policy and International Mergers and Acquisitions - Is the Tax Exemption System Superior?, January 2007

1885 Momi Dahan and Udi Nisan, The Effect of Benefits Level on Take-up Rates: Evidence from a Natural Experiment, January 2007

1886 José García-Solanes, Francisco I. Sancho-Portero and Fernando Torrejón-Flores, Beyond the Salassa-Samuelson Effect in some New Member States of the European Union, January 2007 
1887 Peter Egger, Wolfgang Eggert and Hannes Winner, Saving Taxes Through Foreign Plant Ownership, January 2007

1888 Timothy J. Goodspeed and Andrew Haughwout, On the Optimal Design of Disaster Insurance in a Federation, January 2007

1889 Wim Groot, Henriëtte Maassen van den Brink and Bernard van Praag, The Compensating Income Variation of Social Capital, January 2007

1890 Bas Jacobs, Ruud A. de Mooij and Kees Folmer, Analyzing a Flat Income Tax in the Netherlands, January 2007

1891 Hans Jarle Kind, Guttorm Schjelderup and Frank Stähler, Newspapers and Advertising: The Effects of Ad-Valorem Taxation under Duopoly, January 2007

1892 Erkki Koskela and Rune Stenbacka, Equilibrium Unemployment with Outsourcing under Labour Market Imperfections, January 2007

1893 Maarten Bosker, Steven Brakman, Harry Garretsen, Herman de Jong and Marc Schramm, The Development of Cities in Italy 1300 - 1861, January 2007

1894 Michel Beine, Oscar Bernal, Jean-Yves Gnabo and Christelle Lecourt, Intervention Policy of the BoJ: A Unified Approach, January 2007

1895 Robert S. Chirinko and Daniel J. Wilson, State Investment Tax Incentives: A Zero-Sum Game?, January 2007

1896 Theo S. Eicher and Oliver Roehn, Sources of the German Productivity Demise Tracing the Effects of Industry-Level ICT Investment, January 2007

1897 Helge Berger, Volker Nitsch and Tonny Lybek, Central Bank Boards around the World: Why does Membership Size Differ?, January 2007

1898 Gabriel Felbermayr and Wilhelm Kohler, Does WTO Membership Make a Difference at the Extensive Margin of World Trade?, January 2007

1899 Benno Torgler and Friedrich Schneider, The Impact of Tax Morale and Institutional Quality on the Shadow Economy, January 2007

1900 Tomer Blumkin and Efraim Sadka, On the Desirability of Taxing Charitable Contributions, January 2007

1901 Frederick van der Ploeg and Reinhilde Veugelers, Higher Education Reform and the Renewed Lisbon Strategy: Role of Member States and the European Commission, January 2007

1902 John Lewis, Hitting and Hoping? Meeting the Exchange Rate and Inflation Criteria during a Period of Nominal Convergence, January 2007 
1903 Torben M. Andersen, The Scandinavian Model - Prospects and Challenges, January 2007

1904 Stephane Dees, Sean Holly, M. Hashem Pesaran and L. Vanessa Smith, Long Run Macroeconomic Relations in the Global Economy, January 2007

1905 Richard Jong-A-Pin and Jakob De Haan, Political Regime Change, Economic Reform and Growth Accelerations, January 2007

1906 Sascha O. Becker and Peter H. Egger, Endogenous Product versus Process Innovation and a Firm's Propensity to Export, February 2007

1907 Theo S. Eicher, Chris Papageorgiou and Oliver Roehn, Unraveling the Fortunates of the Fortunate: An Iterative Bayesian Model Averaging (IBMA) Approach, February 2007

1908 Liliana E. Pezzin, Robert A. Pollak and Barbara S. Schone, Efficiency in Family Bargaining: Living Arrangements and Caregiving Decisions of Adult Children and Disabled Elderly Parents, February 2007

1909 Christian Keuschnigg and Soren Bo Nielsen, Self-Selection and Advice in Venture Capital Finance, February 2007

1910 Rune Jansen Hagen and Gaute Torsvik, Irreversible Investments, Dynamic Inconsistency and Policy Convergence, February 2007

1911 Eric A. Hanushek and Ludger Woessmann, The Role of School Improvement in Economic Development, February 2007

1912 Bernard M. S. van Praag, Perspectives from the Happiness Literature and the Role of New Instruments for Policy Analysis, February 2007

1913 Volker Grossmann and Thomas M. Steger, Growth, Development, and Technological Change, February 2007

1914 Margarita Katsimi and Thomas Moutos, Human Capital and the Feldstein-Horioka Puzzle, February 2007

1915 Oliver Roehn, Theo S. Eicher and Thomas Strobel, The Ifo Industry Growth Accounting Database, February 2007 